\title{
牛蒡の開花と結實に關する二三の調査
}

\author{
安藤茂泫 \\ 門 田 寅 太 郎
}

（新潟縣農事試驗埸墽藝部）

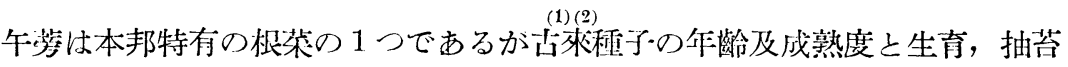

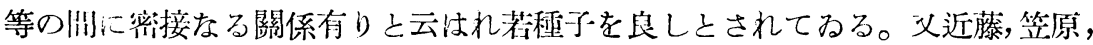

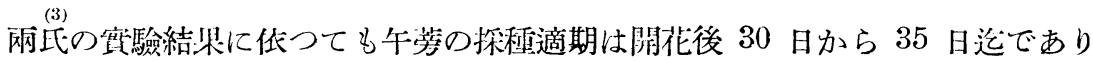

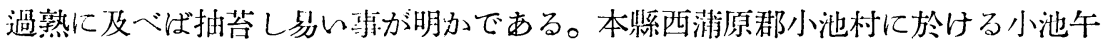
蓉採程組合では探種期を $3 ， 4$ 四に分けて成熟した程子より順次收穫を行つて わるっか〉る採種上の立場から或しは育程の基礎上して開花, 授粉, 結賽の研

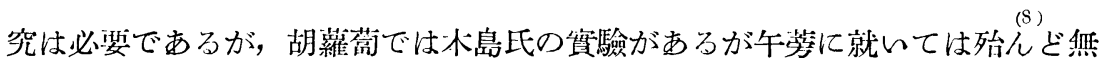
いよ云つてよい。本調查は越後地方の環境下に於ける午蒡の開花, 授粉, 結實 に就いて敬察調枯の第 1 步として行つたもので授粉等に關しては倘精密なる實 驗在必荘とするのであるが得たる調柋の $2 ， 3$ の結果を此處に教告するととに する、調查の手傅ひには助手三州川紀一君及藤田元三郎君が之に當つて吳れた。

\section{1. 調查の材料及方法}

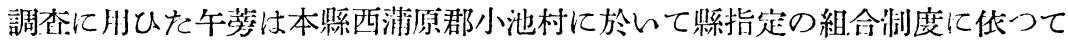

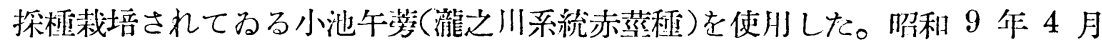
20 日原々種子·播種，同年 11 月下旬村本の憸查をなし根部の發蓇中等をる の 30 本を選びて定植なし翌春師ち沿和 10 年 5 月抽苔， 7 月中旬開花を待ち て開花授粉の調查を始め，9月14日一齊に刈取り調杢筀に運んで結實の調查 在なした。一個體に於ける開花順序，結實等の調查には頭狀花等に開花月日及 頭狀花番號を附した紙片の小ラベルを附し，1 頭䟮花中の筒㣍花の開花調查は

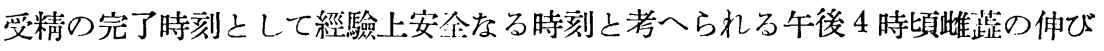
たるものをピンセットにて摘み去つて數を讀み記帖した。自家授精の調查は 1 株を蚊帳張りの探種籠にて被ひ紋白蝶の卵を入れ孵化後 1 個體間の花粉媒助を 


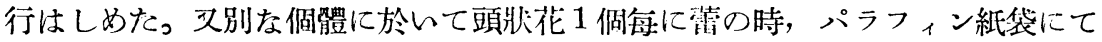
被ひ，更に文頭狀花中の 1 简爿花のみを殘してパラフィン紙袋を被ふ等の力法 に依つて自然放任之の比較 調杢在行つた。

投精時刻谁察方法として は開花せる頭爿花に對し各 時刻別に花柱を根元より摘 み去つて種丁の稔寞數を數 へて之を察知する哥にし た。結實調龺は刚取後頭妝 花別に乾燥, 調製をなし老 實種子，料を 1 粒づ〉選別

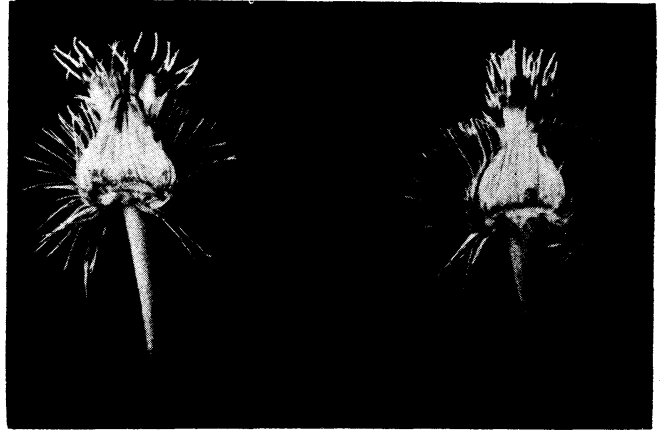

A

第 1 圖 牛蒡の頭狀花の開花

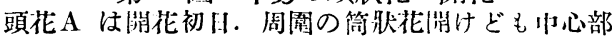
は未粠である

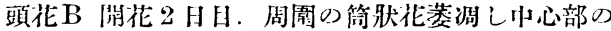
七0開花中

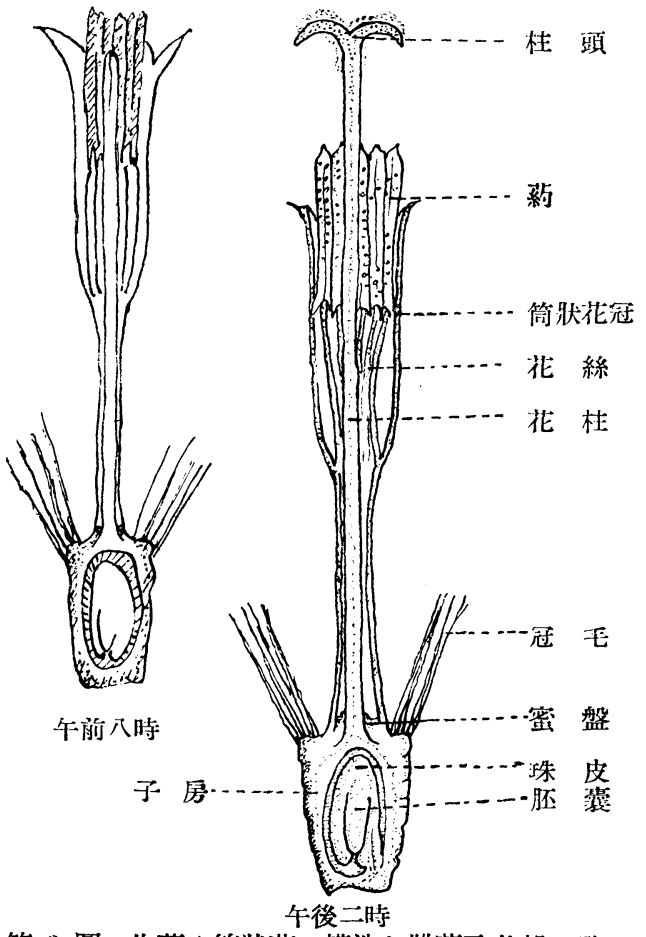

第 2 圖 牛蒡 1 筒狀花の構造と雌蕋及各部の發 育を示す $(\times 16)$
して科量或ひは數圭賈ん だ。

\section{2. 調查の成績}

1 阙花調䄳

(A) 開花状涊（符 $1 ， 2$

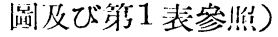

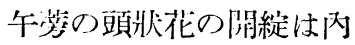
部に包まれた简跃花か開花 せんとして總苍を內部加ら 抑阙く㖊に依つて始まる。 朝 7 時顷より頭狀花內の周 䢬部の简㸝花は徐々に伸唇 發育を始好简彇花瓣の裂片 讨紅紫色老深为總苍の頂部 より其の先端を僅に簬はす に到る。此時雌芷业の柱の二 裂片々合掌狀にて䇠狀の聚 


\begin{tabular}{|c|c|c|c|}
\hline 時 & 筒狀花瓣つ長さ & 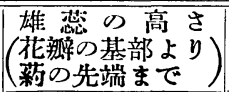 & 雌㥕の長さ \\
\hline 午 前 8 時 & $\begin{array}{r}\mathrm{mm} \\
14.00\end{array}$ & \begin{tabular}{r|}
$\min$ \\
14.4
\end{tabular} & $\begin{array}{r}\text { Inm } \\
13.90\end{array}$ \\
\hline 午 前 11 時 & 14.99 & 16.6 & 16.00 \\
\hline 午 後 1 時 & 15.00 & 17.4 & 20.10 \\
\hline
\end{tabular}

萂の內に納ま

つて居て花瓣 と葯との先端 は同高である 然し紫色在增 した跔は既に

\begin{tabular}{|c|c|c|c|c|c|c|}
\hline $\begin{array}{ll}\text { 個 } & \text { 體 } \\
\text { 號 }\end{array}$ & $\begin{array}{l}\text { 花苔の } \\
\text { 高さ }\end{array}$ & 分校數 & 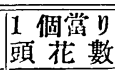 & 開花始 & 開花終 & $\begin{array}{ll}\text { 開 } & \text { 㔨 } \\
\text { 期 } & \text { 間 }\end{array}$ \\
\hline 1 & $\begin{array}{r}\mathrm{m} \\
1.200\end{array}$ & 11 & 145 & $\begin{array}{c}\text { 月 } \\
7-14\end{array}$ & $\begin{array}{c}\text { 月 } \\
8-20\end{array}$ & $37^{\text {구 }}$ \\
\hline 2 & 0.980 & 8 & 113 & $7-16$ & $8-17$ & 32 \\
\hline 3 & 0.950 & 9 & 83 & $7-19$ & $8-16$ & 28 \\
\hline 4 & 1.010 & 11 & 149 & $7-16$ & $8-19$ & 34 \\
\hline 5 & 1.090 & 10 & 128 & $7-17$ & $8-20$ & 34 \\
\hline 6 & 1.180 & 11 & 127 & $7-15$ & $8-19$ & 35 \\
\hline 7 & 1.130 & 10 & 133 & $7-17$ & $8-15$ & 29 \\
\hline 8 & 1.070 & 10 & 123 & $7-20$ & $8-21$ & 32 \\
\hline 9 & 1.080 & 8 & 82 & $7-17$ & $8-18$ & 32 \\
\hline 10 & 1.120 & 8 & 121 & $7-18$ & $8-19$ & 32 \\
\hline 本 均 & 1.080 & 9.6 & 120.4 & $7-16.9$ & $8-18.4$ & 32.5 \\
\hline
\end{tabular}
此の時 (8 時) 開い て稍粘留ではあるが 花粉考萂壁まで押出 してるる。9 時より 10 時頃に及バば杜 頭甚だ微かに紅紫色 を带び花柱は伂長し て行くが花辦及雄䓱 の發達が大である爲 め 11 時まで杜頭を 出す事出來ない。

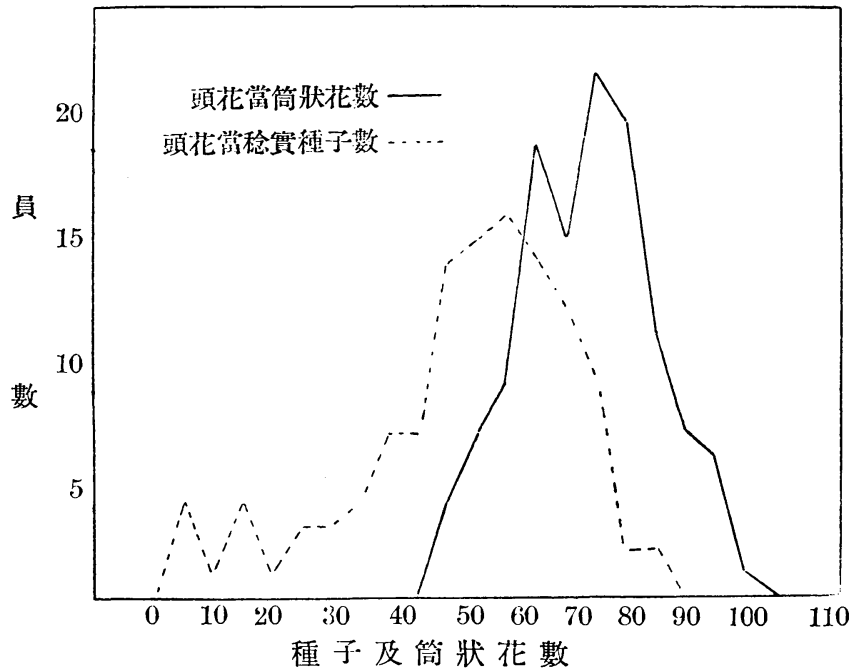

11 時より 12 時 にかけて雌茈は 急激志る伸舆を なし楬の內壁の 花粉を多量に柱 頭に被つて聚彩 外へ 3 粔酴り管 出でる。杜頭は 父分し，先端に 附着した花粉は 父分の內面に落 第 3 圖 牛蒡の 1 頭花の種子及筒狀花數の變異 ちる。熊蜂の來 
訪に化つて各杜頭は自他の花粉を多量に受ける。午後 1 時以後は殆んど伸長を 見るととをく翌日に到つて此等の筒狀花は萎调し中心部の筒狀花が開花を始め る順序(無限的花序)となる。頭狀花の開花始めは第 2 表に見る如く 10 本の平 均 7 月 16.9 日開花終り 8 月 18.4 日で期間は 32.5 日であり 1 株平均 120.4 の頭狀 花を附けた。最も大なる株は 300 以上も附けたるのもあるが極めて稀である。 1 頭花當りの平均筒狀花數は 73.82 であつて（第 3 圖參照）大部分 2 日で癸き 終へる。極く稀に 1 日で終へ或ひは 3 日からるものも市る。 3 日のものは第 2 日目の開花數が一番多い。以上の如く開花の習性は菊及チシヤに谌だ類似して

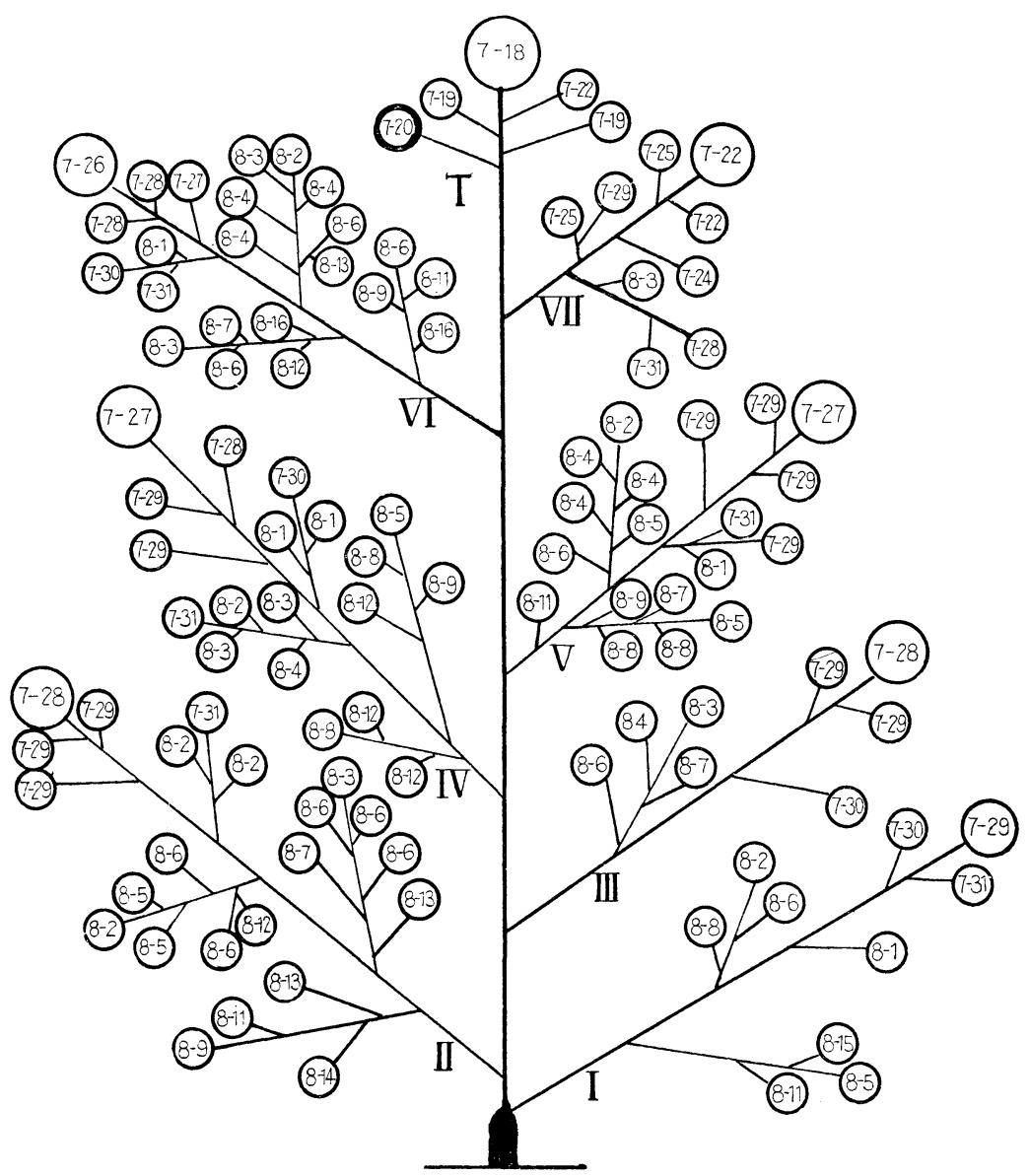

第 4 圖 牛蒡の開花順序模式圖

I，II は第一，第二主校を表す。Tは主蔡を示す 
みるが 1 頭花の開花期間がチシャは 1 日中の短時間で終り菊類は 4-15 日か る事に比べると午蒡は中䦥に位してるるととになる。

(B) 觕花の順序と期閔

1 株上に於ける開花順序は數多くの株を壮均する票は却つて面倒になるので 第2 表の 10 個體中平均に近き No. 10 の株の調杢を以つて平均に代へる事に Lた。

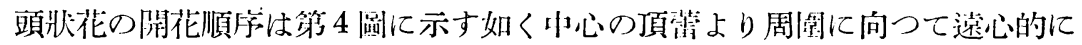
垈いて行く。分伎枝の順序を見るに下部より番踥を打てば開花の順位は主蕉, 第 7 主枝，第 6 ，第 5 及第 4 ，第 3 及第 2 ，第 1 亡なつて上部より下部に 及び有限花序式に進んで行くことが分る。1 分岐枝上の開花期間は（第 6 裴)主

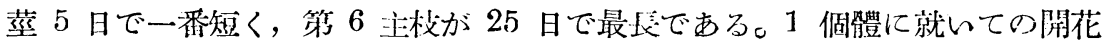
盛期は 7 月下旬より 8 月上旬であつて全期間 31 日の川で 7 月 26 日より 8 月 9 日迄の 15 日间に垈いた頭花數恃全體の $77.6 \%$ であつた（第 7 表及第 5 圖參尖)。

第 3 表分枝別に見たる開花數

\begin{tabular}{|c|c|c|c|c|c|c|c|c|c|c|c|c|c|c|c|c|c|c|c|}
\hline 月日 & $\frac{\text { 第 }}{\text { 枝 }}$ & $=$ & 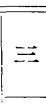 & 四 & 五. & 六 & t & 荎 & 計 & $10 \mathrm{H}$ & $\frac{\text { 第 }}{\text { 枝 }}$ & 二 & $\equiv$ & 四 & 五 & 宍 & $t$ & 圭 & 詁 \\
\hline 18 & - & - & - & - & - & - & - & 1 & 1 & 8.3 & $\cdots$ & 1 & 2 & 2 & - & 2 & 1 & - & 8 \\
\hline 19 & - & - & - & - & - & - & - & 2 & 2 & 4 & $\ldots$ & - & 1 & 1 & 3 & 3 & - & - & 8 \\
\hline 20 & - & - & - & - & - & - & - & 1 & 1 & 5 & 1 & 2 & 1 & 1 & 2 & - & - & - & 7 \\
\hline 21 & - & $\ldots$ & - & - & -. & - & - & 1 & 1 & 6 & 1 & 5 & 1 & - & 1 & 3 & - & - & 11 \\
\hline 22 & - & - & - & - & - & - & 1 & - & 1 & 7 & - & 1 & 1 & - & 1 & 1 & $\ldots$ & - & 4 \\
\hline 23 & - & - & - & - & - & - & - & - & 0 & 8 & 1 & 1 & 1 & 2 & 2 & - & - & - & 7 \\
\hline 24 & - & - & - & - & - & - & 2 & - & 2 & 9 & - & - & 1 & 1 & 1 & 1 & - & - & 4 \\
\hline 25 & - & - & - & - & - & - & 2 & - & 2 & 10 & - & - & - & - & - & - & - & - & 0 \\
\hline 26 & - & - & - & - & - & 1 & - & - & 1 & 11 & 1 & 1 & - & - & 1 & 1 & - & - & 4 \\
\hline 27 & - & - & - & 1 & 1 & 1 & - & - & 3 & 12 & - & 1 & - & 3 & - & 1 & - & - & 5 \\
\hline 28 & - & 1 & 1 & 1 & - & 2 & 1 & - & 6 & 13 & - & 2 & - & - & --- & 1 & - & 一 & 3 \\
\hline 29 & 1 & 3 & 2 & 2 & 4 & $\ldots$ & 1 & - & 13 & 14 & - & 1 & 1 & -1 & - & -1 & - & - & 2 \\
\hline 30 & 1 & - & 1 & 1 & - & 1 & - & - & 4 & 15 & 1 & - & - & $\ldots$ & - & - & - & - & 1 \\
\hline 31 & 1 & 1 & - & 1 & 1 & 1 & 1 & - & 6 & 16 & 一 & - & - & - & - & 1 & - & - & 1 \\
\hline 8. 1 & 1 & - & - & 2 & 1 & 1 & - & - & 5 & 17 & - & - & - & - & - & 1 & - & - & 1 \\
\hline 2 & 1 & 3 & - & 1 & 1 & 1 & $\cdots$ & - & 7 & 計 & 10 & 23 & 13 & 19 & 19 & 23 & 9 & - & 121 \\
\hline
\end{tabular}


第 4 表 牛蒡開花結實に關する(分岐別)調査（昭和 10.10）

\begin{tabular}{|c|c|c|c|c|c|c|c|c|c|c|c|c|c|c|c|}
\hline & \multirow{4}{*}{$\begin{array}{l}\text { 頭 } \\
\text { 花 } \\
\text { 番 } \\
\text { 號 }\end{array}$} & \multirow{4}{*}{$\mid \begin{array}{l}\text { 閒の } \\
\text { 花 } \\
日^{\text {遌 }} \\
\text { 順番 }\end{array}$} & \multirow{4}{*}{$\begin{array}{c}\text { 闍 } \\
\text { 花 } \\
\text { 始 } \\
\mu \\
11\end{array}$} & \multicolumn{3}{|c|}{ 筒狀花數 } & \multirow{4}{*}{$\begin{array}{l}\text { 篅 } \\
\text { 爿 } \\
\text { 花 } \\
\text { 總 } \\
\text { 數 }\end{array}$} & \multirow{4}{*}{$\begin{array}{l}\text { 種 } \\
\text { 子 } \\
\text { 總 } \\
\text { 數 }\end{array}$} & \multirow{4}{*}{$\begin{array}{l}\text { 稔 } \\
\text { 锤 } \\
\text { 種 } \\
\vec{\jmath} \\
\text { 數 }\end{array}$} & \multirow{4}{*}{$\begin{array}{l}\text { 粃 } \\
\text { 種 } \\
\text { 子 } \\
\text { 数 }\end{array}$} & \multirow{4}{*}{$\begin{array}{l}\text { 稔 } \\
\text { 貫 } \\
\%\end{array}$} & \multirow{4}{*}{$\begin{array}{l}\text { 䅦 } \\
\text { 荳 } \\
\text { 種 } \\
\text { 子 } \\
\text { 重 } \\
\text { 量 }\end{array}$} & \multirow{4}{*}{$\begin{array}{l}\text { 稔一 } \\
\text { 䔈 } \\
\text { 種 } \\
\text { 子重 }\end{array}$} & \multirow{4}{*}{$\begin{array}{l}\text { 總 } \\
\text { 種 } \\
\text { 子 } \\
\text { 重 } \\
\text { 量 }\end{array}$} & \multirow{4}{*}{ 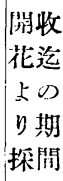 } \\
\hline & & & & & 同 & 瀜 & & & & & & & & & \\
\hline & & & & & 2 & & & & & & & & & & \\
\hline & & & & 化目 & 自 & 1 & & & & & & & & & \\
\hline \multirow{4}{*}{ 第 } & 1 & 12 & $7.29 \mid$ & 58 & 25 & -.- & 83 & 83 & 66 & 17 & 79.51 & $\begin{array}{l}\mathrm{mig} \\
820\end{array}$ & $\begin{array}{r}\mathrm{mg} \\
12.42\end{array}$ & & \\
\hline & 2 & 13 & 7.30 & 66 & 7 & - & 73 & 73 & 61 & 12 & 83.56 & 790 & 12.95 & 820 & 46 \\
\hline & 3 & 14 & 7.31 & 7 & 60 & - & 67 & 67 & 58 & 9 & 86.56 & 710 & 12.24 & 720 & 45 \\
\hline & 4 & 15 & 8. 1 & 30 & 45 & 6 & 81 & 81 & 65 & 16 & 80.24 & 850 & 13.07 & 880 & 43 \\
\hline \multirow{3}{*}{ 主 } & 5 & 16 & 2 & 6 & 69 & $\cdots$ & 75 & 75 & 68 & 7 & 90.66 & 880 & 12.94 & 900 & 43 \\
\hline & 6 & 19 & 5 & 19 & 54 & 一 & 73 & 73 & 18 & 55 & 24.65 & 240 & 13.33 & 320 & 40 \\
\hline & 7 & 20 & 6 & 45 & 20 & - & 65 & 65 & 17 & 48 & 26.15 & 190 & 11.17 & 260 & 39 \\
\hline \multirow[t]{7}{*}{ 校 } & 8 & 22 & 8 & 54 & 9 & - & 63 & 63 & 38 & 25 & 60.31 & 500 & 13.15 & 620 & 37 \\
\hline & 9 & 25 & 11 & 25 & 41 & - & 66 & 66 & 50 & 16 & 75.75 & 630 & 12.60 & 670 & 34 \\
\hline & 10 & 29 & 15 & 36 & 12 & - & 48 & 48 & 34 & 14 & 70.83 & 390 & 11.47 & 430 & 29 \\
\hline & 1 & 11 & 7.28 & 71 & 13 & - & 84 & 84 & 73 & 11 & 86.90 & 960 & 13.15 & 1010 & 48 \\
\hline & 2 & 12 & 29 & 31 & 37 & - & 68 & 68 & 48 & 20 & 70.58 & 660 & 13.75 & 750 & 47 \\
\hline & 3 & 12 & 29 & 28 & 51 & $\cdots$ & 79 & 79 & 66 & 13 & 83.54 & 920 & 13.93 & 990 & 47 \\
\hline & 4 & 12 & 29 & 33 & 43 & -- & 76 & 76 & 61 & 15 & 80.26 & 770 & 12.62 & 840 & 47 \\
\hline & 5 & 14 & 31 & 73 & 8 & - & 81 & 81 & 60 & 21 & 74.07 & 790 & 13.16 & 870 & 45 \\
\hline \multirow[t]{4}{*}{ 第 } & 6 & 16 & 8.2 & 76 & 6 & - & 82 & 82 & 73 & 9 & 89.02 & 810 & 11.09 & 840 & 43 \\
\hline & 7 & 16 & 2 & 65 & 8 & - & 73 & 73 & 58 & 15 & 79.45 & 770 & 13.27 & 810 & 43 \\
\hline & 8 & 16 & 2 & 68 & 25 & - & 93 & 93 & 80 & 13 & 86.0 & 790 & 9.87 & 800 & 43 \\
\hline & 9 & 17 & 3 & 66 & - & - & 66 & 66 & 55 & 11 & 83 & 810 & 14.72 & 850 & 43 \\
\hline \multirow[t]{4}{*}{$=$} & 10 & 19 & 5 & 42 & 20 & 一 & 62 & 62 & 35 & 27 & 56.45 & 360 & 10.28 & 400 & 40 \\
\hline & 11 & 19 & 5 & 70 & 8 & - & 78 & 78 & 16 & 52 & 20.51 & 160 & 10.00 & 520 & 40 \\
\hline & 12 & 20 & 6 & 61 & 16 & - & 77 & 77 & 14 & 63 & 18.18 & 140 & 10.00 & 220 & 39 \\
\hline & 13 & 20 & 6 & 18 & 59 & - & 77 & 77 & 25 & 52 & 32.46 & 290 & 11.60 & 390 & 39 \\
\hline \multirow[t]{4}{*}{ 主 } & 14 & 20 & 6 & 54 & 2 & - & 56 & 56 & 1 & 55 & 1.78 & 10 & 10.00 & 140 & 39 \\
\hline & 15 & 20 & 6 & 70 & - & - & 70 & 70 & 一 & 70 & - & - & $\cdots$ & 240 & 40 \\
\hline & 16 & 20 & 6 & 64 & - & - & 64 & 64 & 一. & 64 & - & - & - & 180 & 40 \\
\hline & 17 & 21 & 7 & 48 & 20 & - & 68 & 68 & 49 & 19 & 72.05 & 640 & 13.06 & 740 & 38 \\
\hline \multirow{6}{*}{ 校 } & 18 & 22 & 8 & 29 & 31 & - & 60 & 60 & 54 & 6 & 90.00 & 630 & 11.66 & 660 & 37 \\
\hline & 19 & 25 & 11 & 41 & 9 & 一 & 50 & 50 & 47 & 3 & 94.00 & 560 & 11.91 & 560 & 34 \\
\hline & 20 & 26 & 12 & 19 & 35 & - & 54 & 54 & 6 & 48 & 11.11 & 50 & 8.33 & 130 & 33 \\
\hline & 21 & 27 & 13 & 8 & 35 & 14 & 57 & 57 & 32 & 25 & 56.14 & 400 & 12.50 & 460 & 31 \\
\hline & 22 & 27 & 13 & 13 & 58 & - & 71 & 71 & 38 & 33 & 53.52 & 480 & 12.63 & 580 & 32 \\
\hline & 23 & 28 & 14 & 51 & 2 & 一 & 53 & 53 & 30 & 23 & 56.60 & 360 & 12.00 & 390 & 31 \\
\hline
\end{tabular}




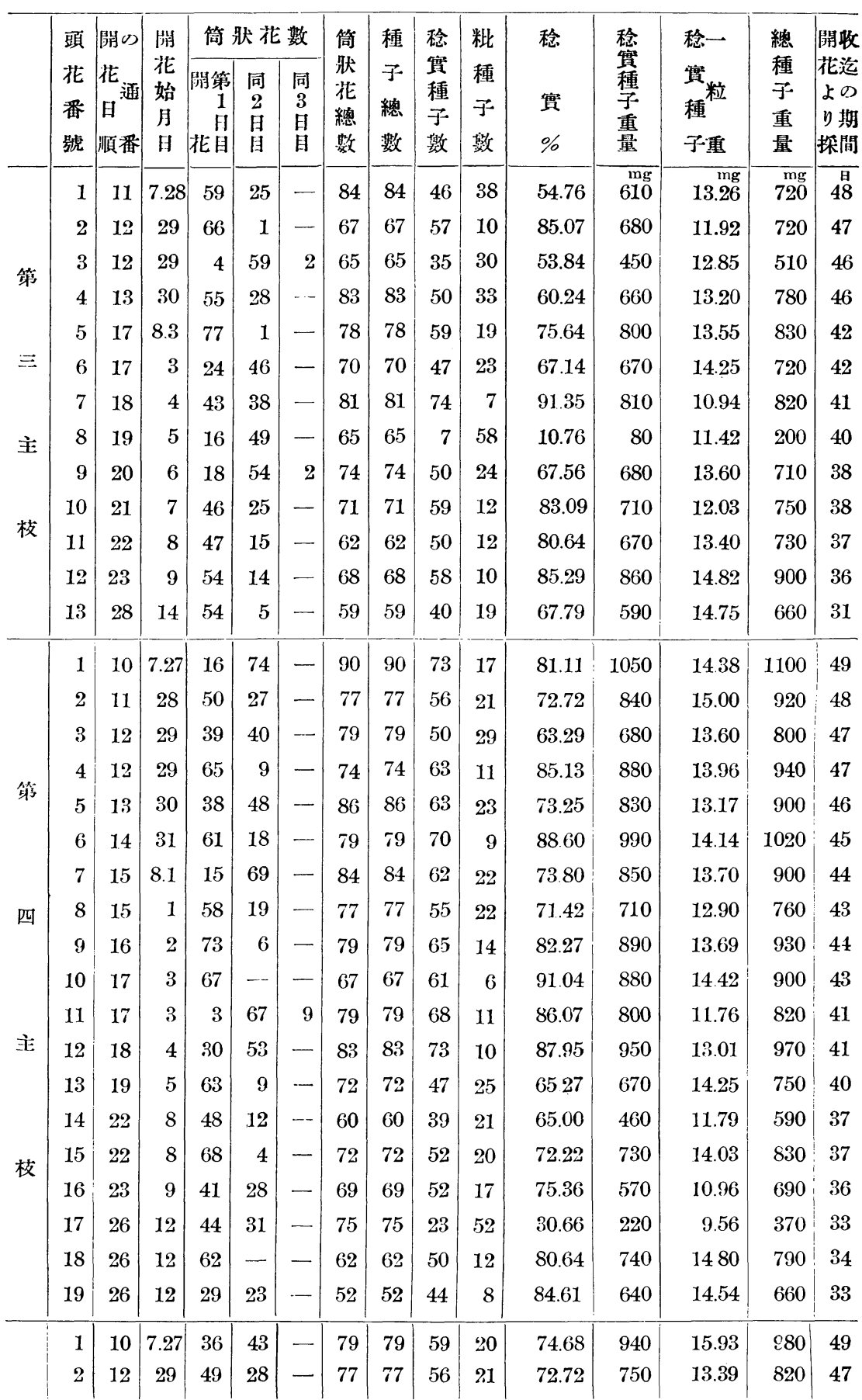




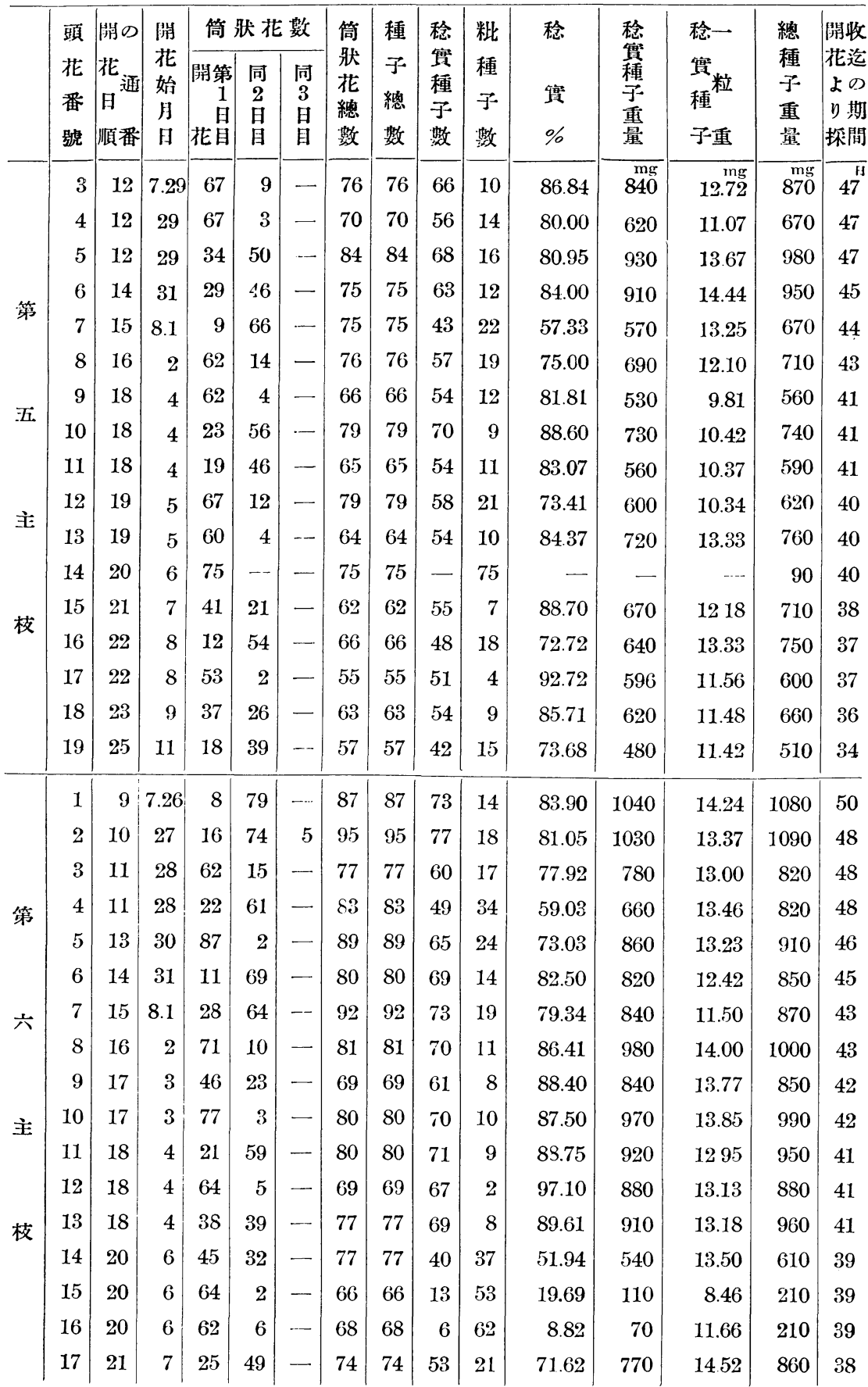




\begin{tabular}{|c|c|c|c|c|c|c|c|c|c|c|c|c|c|c|c|}
\hline & \multirow{2}{*}{$\begin{array}{l}\text { 頭 } \\
\text { 花 } \\
\text { 番 } \\
\text { 號 }\end{array}$} & \multirow{2}{*}{ 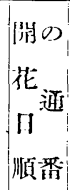 } & \multirow{2}{*}{ 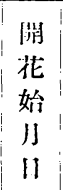 } & \multicolumn{3}{|c|}{ 简狀花敏 } & \multirow{2}{*}{$\begin{array}{l}\text { 简 } \\
\text { 獎 } \\
\text { 花 } \\
\text { 總 } \\
\text { 數 }\end{array}$} & \multirow{2}{*}{$\begin{array}{c}\text { 種 } \\
\text { 子 } \\
\text { 總 } \\
\text { 葴 }\end{array}$} & \multirow{2}{*}{$\begin{array}{l}\text { 稔 } \\
\text { 蒀 } \\
\text { 種 } \\
\text { 子 } \\
\text { 數 }\end{array}$} & \multirow{2}{*}{$\begin{array}{l}\text { 粃 } \\
\text { 種 } \\
\text { 子 } \\
\text { 数 }\end{array}$} & \multirow{2}{*}{$\begin{array}{l}\text { 稔 } \\
\text { 寒 } \\
\%\end{array}$} & \multirow{2}{*}{ 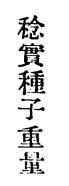 } & \multirow{2}{*}{$\begin{array}{l}\text { 稔一 } \\
\text { 實 } \\
\text { 種 } \\
\text { 子重 }\end{array}$} & \multirow{2}{*}{$\begin{array}{l}\text { 總 } \\
\text { 種 } \\
\text { 子 } \\
\text { 重 } \\
\text { 量 }\end{array}$} & \multirow{2}{*}{$\begin{array}{l}\text { 開收 } \\
\text { 花过 } \\
\text { 上D } \\
\text { り期 } \\
\text { 探閏 }\end{array}$} \\
\hline & & & & $\begin{array}{l} \\
1 \\
1 \\
1 \\
1\end{array}$ & $\begin{array}{l}\text { 同 } \\
2 \\
1] \\
\forall\end{array}$ & $\begin{array}{c}\text { 同 } \\
3 \\
\text { 日 } \\
\text { 甚 }\end{array}$ & & & & & & & & & \\
\hline & 18 & 23 & 9 & 54 & 10 & - & 64 & 64 & 49 & 15 & 76.56 & $\begin{array}{r}\mathrm{mg} \\
690\end{array}$ & 14.08 & 770 & $\begin{array}{r}\text { 日 } \\
35\end{array}$ \\
\hline & 19 & 25 & 11 & 29 & 23 & - & 52 & 52 & 37 & 15 & 71.15 & 530 & 14.32 & 600 & 34 \\
\hline 六 & 20 & 26 & 12 & 63 & 2 & - & 65 & 65 & 57 & 8 & 87.69 & 790 & 13.85 & 820 & 33 \\
\hline İ: & 21 & 27 & 13 & 51 & 4 & -.- & 55 & 55 & 47 & 8 & 85. & 600 & 12.76 & 620 & 32 \\
\hline \multirow[t]{3}{*}{ 校 } & 22 & 30 & 16 & 26 & 35 & - & 61 & 61 & 26 & 35 & 42.6 & 370 & 14.23 & 490 & 29 \\
\hline & 23 & 31 & 17 & 23 & 32 & 4 & 59 & 59 & 12 & 47 & 20.33 & 130 & 10.83 & 260 & 27 \\
\hline & 1 & 5 & 7.22 & 6 & 84 & - & $\varsigma 0$ & 90 & 68 & 22 & & 800 & 11.76 & 910 & 54 \\
\hline \multirow[t]{2}{*}{ 第 } & 2 & 7 & 24 & 56 & 41 & - & 97 & 97 & 72 & 25 & 74.22 & 1000 & 13.88 & 1040 & 52 \\
\hline & 3 & 7 & 24 & 75 & 13 & - & 88 & 88 & 65 & 23 & 73.86 & 900 & 13.84 & 940 & 52 \\
\hline \multirow[t]{2}{*}{ t } & 4 & 8 & 25 & 68 & 21 & - & 89 & 89 & 41 & 48 & 46.06 & 510 & 12.43 & 600 & 51 \\
\hline & 5 & 8 & 25 & 13 & 73 & 8 & 94 & 94 & 65 & 29 & 69.14 & 750 & 11.53 & 810 & 50 \\
\hline \multirow[t]{2}{*}{ 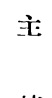 } & 6 & 11 & 28 & 83 & 19 & - & 102 & 102 & 83 & 19 & 81.37 & 970 & 11.68 & 1000 & 48 \\
\hline & 7 & 12 & 29 & 1 & 80 & 8 & 89 & 89 & 76 & 13 & 85.39 & 980 & 12.89 & 1010 & 46 \\
\hline & 8 & 14 & 31 & 45 & 36 & - & 81 & 81 & 58 & 23 & & 800 & 13.79 & 850 & 45 \\
\hline & 9 & 17 & 8.3 & 68 & 19 & - & 87 & 87 & 69 & 18 & 79.31 & 640 & 9.27 & 670 & 42 \\
\hline \multirow{3}{*}{ 主: } & 1 & 1 & 7.18 & 27 & 65 & 2 & 94 & 94 & 82 & 12 & & 1010 & 12.31 & 1050 & 57 \\
\hline & 2 & 2 & 19 & 21 & 67 & 8 & 96 & 96 & 66 & 30 & & 960 & 14.54 & 1040 & 56 \\
\hline & 3 & 2 & 19 & 4 & 68 & 8 & 80 & 80 & 62 & 18 & 77.50 & 880 & 14.19 & 930 & 56 \\
\hline & 4 & 3 & 20 & 80 & 18 & -- & 98 & 98 & 87 & 11 & 88.77 & 1200 & 13.79 & 1230 & 56 \\
\hline & 5 & 4 & 21 & 51 & 18 & - & 69 & 69 & 30 & 39 & 43.47 & 440 & 14.66 & 560 & 55 \\
\hline
\end{tabular}

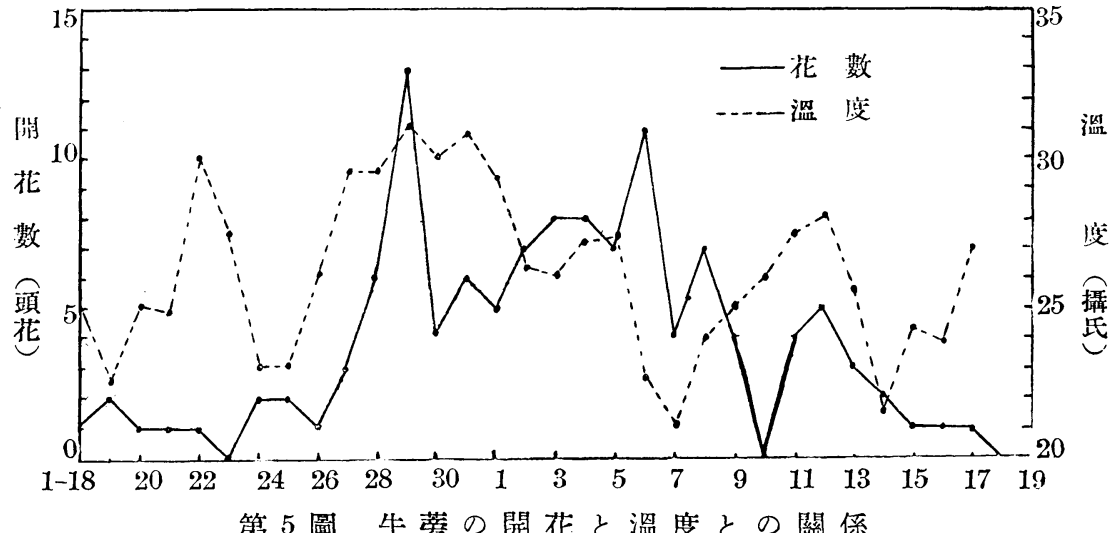

第 5 圖 牛蒡の開花と溫度との關係 


\section{（C）開花之天候との關係}

第 5 圖に示す如く溫度を開花とは關係あるが如くである。低溫は開花を抑へ 高溫は促進してみる傾向が見られる。雨は開花をさまたげてみない。

2. 授粉及結實調查

\section{（A）授精の時刻（下表參照）}

\begin{tabular}{|c|c|c|c|c|c|}
\hline 去雌特帹 & 午前 9 時 & 午前10時 & 寺午前11時 & 寺 $\left[\begin{array}{cc}\text { 年前 } 11 \text { 時 } \\
\text { 端 } \\
\text { 剪 } & \text { 除 }\end{array} \mid\right.$ & 正 \\
\hline 稳實\% & 0 & 6.00 & 6.10 & 62.43 & 59.03 \\
\hline
\end{tabular}

授精の時刻を知るには精密 をる顯微鏡的研究を必要とす るが此の際雌龁を拔き去つた 時刻之稔實度とに低つて簡易

に大體の狀沉を察知せんとしたのであるが調查が極小規模で個體數も少く正確 は期し難いが各區平均して見ると 10 時から 11 時にかけて少數の早いものの 受精が始まり 12 時には大部分が受精してるる模梯である。11時に雌踏を拔き 去つたものと同時刻に柱頭部 3 分の 1 を切つたものとの間に稔實度に大差のあ るのは同時刻に多數の花粉が花柱內一進入してるる事が考へ得られる H. A. JoNeS 茋はチシヤの受精が授粉後 3 - 5 時間位の短時間で行はれる之報じてる るが恐らく牛菩も相當速かに行はれるものではあるまいか。

(B) 自殖亡交雜

第 5 表に示すが如く 1 個體を採種籍に入れ蝶を入れて自殖せしめたものと自 然放任のものを比較してみると稔實度は前者が $68.97 \%$ に比して後者は 63.36 \%であつて優るとも劣つては居ない。1 頭花につき自殖したものが 1 個體自殖 に比べて劣るのは昆蛅を入れなかつた爲めであらう。1 筒狀花を自殖せしめた ものが稔實度 $33.88 \%$ を示して 1 頭花自殖の $51.51 \%$ に劣るは1頭花內に唯 1 個の筒狀花在殘す爲め機械的障碍考受け易い結果之考へられる。牛管の筒狀花 は花の構造から見て自家受精をなす機會の方が多いと云へる。昆品の來訪が受 精を良くするとすればそれは他家の花粉を持ち來る篇めばかりで無くて吡路が 自家授粉を一首援助した雼めでもあらう。郎ち牛蒡の授粉は自殖を立前とする が交雜亦可であつて適期に柱頭裂片の內面に良く附着して哭れれば花粉の自他 は大して䦓はないるのの如く推察出來る。此の點胡蘿䓒に類似してるる。

（C）結實に關する調查 
第 5 表 I 1 個體內の自殖と稔實\% 第 5 表 III 1 筒狀花の自殖と稔實 $\%$

\begin{tabular}{|c|c|c|c|c|c|c|c|c|c|c|c|}
\hline \multirow{2}{*}{\multicolumn{2}{|c|}{ 授枌方泣 }} & \multirow{2}{*}{\multicolumn{2}{|c|}{ 自 殖 株 }} & \multirow{2}{*}{\multicolumn{2}{|c|}{$\begin{array}{l}\text { 自 然 } \\
\text { 放 任 株 }\end{array}$}} & \multirow{2}{*}{$\begin{array}{c}\text { 筒狀花 } \\
\text { No. }\end{array}$} & \multicolumn{4}{|c|}{ 種 } & \multirow[b]{2}{*}{ 稔實 \% } \\
\hline & & & & & & & 總 & 数 & $\begin{array}{ll}\text { 䅦 } & \text { 蒀 } \\
\text { 種 }\end{array}$ & 粃 & \\
\hline \multirow{3}{*}{\multicolumn{2}{|c|}{$\begin{array}{l}\text { 頭 花 數 } \\
\text { 總 種子 數 } \\
\text { 稔實 種子數 }\end{array}$}} & \multicolumn{2}{|c|}{129} & & 158 & 1 & & 1 & 0 & 1 & $\mathbf{0}$ \\
\hline & & \multicolumn{2}{|c|}{6278} & & 9832 & 2 & & 1 & 1 & 0 & 100 \\
\hline & & \multicolumn{2}{|c|}{4330} & & 6230 & 3 & & 1 & 1 & 0 & 100 \\
\hline 偨 & の 基 & \multicolumn{2}{|c|}{1948} & & 3602 & 4 & & 1 & 0 & 1 & $\mathbf{0}$ \\
\hline 稔 & 實 & \multirow{2}{*}{\multicolumn{2}{|c|}{$\begin{array}{r}68.97 \\
\mathrm{mg} \\
59350\end{array}$}} & & 63.36 & 5 & & 1 & 0 & 1 & $\mathbf{0}$ \\
\hline 稔貫 & 種子·重㝵 & & & & 78690 & 6 & & 1 & 0 & 1 & $\mathbf{0}$ \\
\hline \multirow{2}{*}{\multicolumn{2}{|c|}{ 同 上 1 粒 重 }} & \multicolumn{2}{|c|}{$\begin{array}{r}\mathrm{mg} g \\
13.5\end{array}$} & & $\begin{array}{l}\operatorname{lng} \\
12.6\end{array}$ & 7 & & 1 & 1 & 0 & 100 \\
\hline \multirow{2}{*}{\multicolumn{2}{|c|}{ 種子發芽勢 }} & \multirow{2}{*}{\multicolumn{2}{|c|}{64}} & & & 8 & & 1 & 0 & 1 & $\mathbf{0}$ \\
\hline & & & & & 76 & 9 & & 1 & 0 & 1 & 0 \\
\hline \multirow{2}{*}{\multicolumn{2}{|c|}{ 第 5 表 II }} & \multirow{2}{*}{\multicolumn{4}{|c|}{1 頭花內の自殖と稔實％ }} & 10 & & 1 & 0 & 1 & $\mathbf{0}$ \\
\hline & & & & & & 11 & & 1 & 1 & 0 & 100 \\
\hline \multirow{2}{*}{$\begin{array}{l}\text { 頭花 } \\
\text { No. }\end{array}$} & \multirow{2}{*}{ 總種子婁 } & \multirow{2}{*}{$\begin{array}{l}\text { 稔實 } \\
\text { 種子數 }\end{array}$} & \multirow{2}{*}{\multicolumn{2}{|c|}{ 粃の數 }} & \multirow{2}{*}{ 稔實 $\%$} & 12 & & 1 & 0 & 1 & 0 \\
\hline & & & & & & 13 & & 1 & 0 & 1 & $\mathbf{0}$ \\
\hline 1 & 53 & 19 & & 34 & 35.85 & 14 & & 1 & 1 & 0 & 100 \\
\hline 2 & 66 & 52 & & 14 & 78.79 & 15 & & 1 & 1 & 0 & 100 \\
\hline 3 & 74 & 39 & & 35 & 52.71 & 16 & & 1 & 0 & 1 & 0 \\
\hline 4 & 44 & 27 & & 17 & 61.37 & 17 & & 1 & 0 & 1 & 0 \\
\hline 5 & 41 & 27 & & 14 & 65.86 & 18 & & 1 & 0 & 1 & 0 \\
\hline 6 & 61 & 46 & & 15 & 75.41 & 19 & & 1 & 0 & 1 & 0 \\
\hline 7 & 76 & 55 & & 21 & 72.37 & 20 & & 1 & 0 & 1 & 0 \\
\hline 8 & 42 & 21 & & 21 & 50.00 & 21 & & 1 & 0 & 1 & 0 \\
\hline 9 & 63 & 21 & & 42 & 33.34 & 22 & & 1 & 1 & 0 & 100 \\
\hline 10 & 44 & 18 & & 26 & 40.91 & 平均 & & 1 & 0.3188 & 0.6812 & 33.88 \\
\hline 11 & 62 & 24 & & 38 & 34.71 & & & & & & \\
\hline 12 & 32 & 27 & & 5 & 84.38 & \multicolumn{6}{|c|}{ 牛蒡は受精しなくとも瘦果は或程度 } \\
\hline 13 & 37 & 15 & & 22 & 40.53 & \multirow{2}{*}{\multicolumn{6}{|c|}{ 迄發達し所謂粃となる。郎ち 1 稞の單 }} \\
\hline 14 & 48 & 26 & & 22 & 64.17 & & & & & & \\
\hline 15 & 64 & 13 & & 51 & 20.32 & 票結賽 & 茄行 & 丁はね & 乙る。故 & に此處 & E江真正 \\
\hline 16 & 56 & 21 & & 35 & 37.50 & の标子 & $\therefore t$ & & 目要右結 & 1 & - bT \\
\hline 17 & 46 & 24 & & 22 & 52.18 & & & & & c & \\
\hline 18 & 32 & 16 & & 16 & 50.00 & 稔費と & 云。 & 言 & 点を便宜 & 上使用 ᄂ & た。 1 \\
\hline 19 & 72 & 31 & & 41 & 43.06 & 個體に & 於 & ナる & 須狀花に & 狱んての & 平均稔 \\
\hline 20 & 62 & 20 & & 42 & 32.53 & 菑\%は & & $66 y$ & ミあつて & 1 頭花 & の筒狀 \\
\hline 平均 & 53.45 & 27.1 & 26 & 35 & 51.51 & 花數 & & & 2. とすれ & ば稔實和 & 1\}子數は \\
\hline
\end{tabular}


5098 となる。着花门部位師ち分肢枝に依る稔苴\%の差異は認め難（第 6 表） むしろ雨量之の方が關係多く第 7 表に見る如く 8 月 5-6 日の大雨は稔實度を $47.90 \%$ 及 $24.23 \%$ ح之著しく低めておる。7 月 18 日開花の一番最初の日大

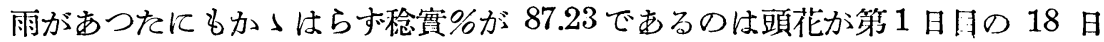
に僅かに 27 個の筒狀花を開を翌日晴天の 19 日に 67 個を開いておろからで

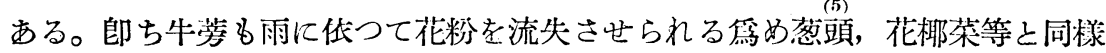
に雨は結實に對して大いに忌む所である。

第 6 表 分岐枝別に見たる開花結實

\begin{tabular}{|c|c|c|c|c|c|c|c|c|c|c|}
\hline $\begin{array}{l}\text { 項目 } \\
\text { 分收 } \\
\text { 枝No }\end{array}$ & $\begin{array}{l}\text { 開花始 } \\
\text { 月 } \text { 日 }\end{array}$ & $\begin{array}{l}\text { 開花終 } \\
\text { 月 }\end{array}$ & 開 & 頭花數 & 筒爿花 & $\begin{array}{l}1 \text { 頭花常 } \\
\text { 数 }\end{array}$ & 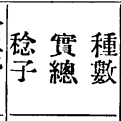 & 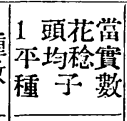 & $\begin{array}{l}\text { 數に依る } \\
\text { 稳實 } \%\end{array}$ & $\begin{array}{l}\text { 䅦實種 } \\
\text { 重 }\end{array}$ \\
\hline 1 & 7.29 & 8.16 & 19 & 10 & 694 & 69.4 & 475 & 47.5 & 75.39 & 12.5 \\
\hline 2 & 7.28 & 8.15 & 19 & 23 & 1599 & 69.5 & 921 & 40.0 & 56.34 & 10.8 \\
\hline 8 & 7.28 & 8.15 & 19 & 13 & 927 & 71.3 & 632 & 48.6 & 67.93 & 13.1 \\
\hline 4 & 7.27 & $8: 13$ & 18 & 19 & 1416 & 74.5 & 1066 & 56.1 & 75.28 & 13.3 \\
\hline 5 & 7.27 & 8.12 & 17 & 19 & 1343 & 70.6 & 1008 & 53.0 & 75.59 & 11.6 \\
\hline 6 & 7.26 & 8.19 & 25 & 23 & 1700 & 73.9 & 1211 & 52.6 & 70.01 & 13.1 \\
\hline 7 & 7.22 & 8. 4 & 14 & 9 & 817 & 90.7 & 597 & 66.3 & 72.94 & 12.3 \\
\hline 主筮 $(\mathrm{T})$ & 7.18 & 7.22 & 5 & 5 & 437 & 87.4 & 327 & 65.4 & 73.14 & 13.9 \\
\hline 計 & & & & & 8933 & & 6237 & & & \\
\hline
\end{tabular}

\begin{tabular}{|c|c|c|c|c|c|c|c|c|}
\hline \multirow{2}{*}{ 分岐 } & \multicolumn{2}{|c|}{ 種子重 量 } & \multicolumn{2}{|c|}{ 稔實種子重量 } & \multirow{2}{*}{$\begin{array}{l}\text { 重量に依 } \\
\text { る稔實\% }\end{array}$} & \multirow{2}{*}{$\begin{array}{l}\text { 種予 } \\
\text { 總容量 }\end{array}$} & \multirow{2}{*}{$\begin{array}{l}\text { 稔钼種于 } \\
\text { 容 }\end{array}$} & \multirow{2}{*}{$\begin{array}{l}\text { 容量に依 } \\
\text { る秢苗\% }\end{array}$} \\
\hline & 總 重 量| & 頭花篗 & 總 重 量|1 & 1 頭花虽 & & & & \\
\hline 1 & 6520 & $6520^{\mathrm{mg}}$ & $6000^{\ln x}$ & $600.0^{\mathrm{my}}$ & $92.02^{\mathrm{w} / 2}$ & $13.4^{\mathrm{ce}}$ & $10.8^{\circ c}$ & 80.59 \\
\hline 2 & 13370 & 581.3 & 11360 & 507.8 & 84.96 & 27.2 & 20.2 & 74.26 \\
\hline 3 & 9050 & 696.1 & 8270 & 636.1 & 91.38 & 18.0 & 15.0 & 83.33 \\
\hline 4 & 15600 & 821.0 & 14380 & 756.8 & 92.17 & 30.4 & 28.0 & 92.10 \\
\hline 5 & 13240 & 696.8 & 12390 & 652.1 & 93.58 & 25.6 & 22.0 & 85.93 \\
\hline 6 & 17520 & 761.7 & 16130 & 701.3 & 92.17 & 33.8 & 27.0 & 79.88 \\
\hline 7 & 7830 & 870.0 & 7350 & 816.6 & 93.86 & 16.0 & 13.2 & 82.50 \\
\hline 主蕉( $\mathrm{T}$ ) & 4810 & 962.0 & 4490 & 898.0 & 93.34 & 10.0 & 8.5 & 85.00 \\
\hline 計 & 87950 & & 80270 & & & 174.4 & 144.7 & \\
\hline
\end{tabular}


第 7 表 開花日別に依る開花數及び稔實度

\begin{tabular}{|c|c|c|c|c|c|c|c|c|c|c|}
\hline & \multirow[b]{2}{*}{ 開花月日 } & \multirow{2}{*}{$\begin{array}{l}\text { 開頭 } \\
\text { 北花 } \\
\text { る數 } \\
\end{array}$} & \multicolumn{3}{|c|}{ 筒狀花總數 } & \multirow{2}{*}{ 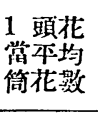 } & \multirow[b]{2}{*}{ 稔實％ } & & \multirow[b]{2}{*}{ 雨 } & \multirow[b]{2}{*}{ 溫 } \\
\hline & & & \begin{tabular}{ll|} 
目时 \\
\end{tabular} & 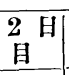 & 計 & & & $\begin{array}{l}\text { 照 } \\
\text { 間 }\end{array}$ & & \\
\hline 1 & $7.18-7.19$ & 1 & 27 & 67 & 94 & 94.0 & 87.23 & 7.2 & $\begin{array}{r}\mathrm{mm} \\
23.8\end{array}$ & $25.0^{\circ}$ \\
\hline 2 & $19-20$ & 2 & 25 & 151 & 176 & 88.0 & 73.12 & 6.7 & 0 & 22.5 \\
\hline 3 & $20-21$ & 1 & 80 & 18 & 98 & 98.0 & 88.77 & 8.7 & 0 & 25.0 \\
\hline 4 & $21-22$ & 1 & 51 & 18 & 69 & 69.0 & 43.47 & 3.2 & 0 & 24.9 \\
\hline 5 & $22-23$ & 1 & 6 & 84 & 90 & 90.0 & 75.55 & 9.6 & 0 & 31.1 \\
\hline 6 & $33-24$ & 0 & - & - & - & - & - & 2.7 & 4.3 & 27.6 \\
\hline 7 & $24-25$ & 2 & 131 & 54 & 185 & 92.5 & 74.04 & 2.9 & 1.3 & 23.0 \\
\hline 8 & $25-26$ & 2 & 81 & 102 & 183 & 91.5 & 57.60 & 1.1 & 0 & 23.1 \\
\hline 9 & $26-27$ & 1 & 8 & 79 & 87 & 87.0 & 83.90 & 10.9 & 0 & 26.1 \\
\hline 10 & $27-28$ & 3 & 71 & 193 & 264 & 88.0 & 78.94 & 9.9 & 0 & 29.6 \\
\hline 11 & $28-29$ & 6 & 347 & 160 & 507 & 84.5 & 72.11 & 10.1 & 0 & 29.5 \\
\hline 12 & $29-30$ & 13 & 550 & 437 & 987 & 75.9 & 77.47 & 9.7 & 0 & 31.0 \\
\hline 13 & $30-31$ & 4 & 246 & 85 & 331 & 82.7 & 72.52 & 9.7 & 0 & 30.0 \\
\hline 14 & $31-8.1$ & 6 & 226 & 237 & 463 & 77.2 & 81.22 & 10.2 & 2.4 & 30.9 \\
\hline 15 & 8. $1-2$ & 5 & 140 & 269 & 409 & 81.8 & 72.42 & 6.7 & 9.3 & 29.2 \\
\hline 16 & $2-\quad 3$ & 7 & 421 & 138 & 559 & 79.8 & $\varepsilon 4.11$ & 2.4 & 2.6 & 26.2 \\
\hline 17 & $3-4$ & 8 & 434 & 162 & 596 & 74.5 & 81.05 & 2.2 & 0 & 26.1 \\
\hline 18 & $4-5$ & 8 & 300 & 300 & 600 & 75.0 & 88.53 & 10.7 & 0 & 27.2 \\
\hline 19 & $5-6$ & 7 & 337 & 156 & 493 & 70.4 & 47.90 & 6.4 & 23.2 & 27.3 \\
\hline 20 & $6-7$ & 11 & 576 & 193 & 769 & 64.9 & 24.23 & 1.3 & 25.4 & 22.6 \\
\hline 21 & $7--8$ & 4 & 160 & 115 & 275 & 68.7 & 78.80 & 2.0 & 0.4 & 21.0 \\
\hline 22 & $8-9$ & 7 & 311 & 127 & 438 & 62.5 & 76.20 & 11.2 & 0 & 24.0 \\
\hline 23 & $9-10$ & 4 & 186 & 78 & 264 & 66.0 & $\varepsilon 0.70$ & 4.3 & 0 & 25.1 \\
\hline 24 & $10-11$ & 0 & - & - & - & - & - & 4.1 & 0 & 26.0 \\
\hline 25 & $11-12$ & 4 & 113 & 113 & 226 & 56.5 & 78.64 & 0 & 0 & 27.5 \\
\hline 26 & $12-13$ & 5 & 217 & 91 & $3 C 8$ & 61.6 & 58.94 & 9.6 & 0 & 28.1 \\
\hline 27 & $13-14$ & 3 & 72 & 111 & 183 & 61.0 & $65 .(3$ & 7.3 & 0 & 25.6 \\
\hline 28 & $14-15$ & 2 & 105 & 7 & 112 & 56.0 & 62.19 & 0 & 0 & 21.6 \\
\hline 29 & $15-16$ & 1 & 36 & 12 & 48 & 48.0 & 70.83 & 11.0 & 0 & 24.4 \\
\hline 30 & $16-17$ & 1 & 26 & 35 & 61 & 61.0 & 42.62 & 0 & 0 & 23.7 \\
\hline 31 & $17-18$ & 1 & 23 & 26 & 59 & 59.0 & 20.33 & 7.9 & 0 & 27.0 \\
\hline & & & & & & & & 6.1 & 23.8 & 25.0 \\
\hline
\end{tabular}




\section{3. 摘 要}

1. 新潟縣中蒲原郡に於て昭和 10 年度, 牛蒡の開花結實に就て觀察調查を 行つた。

2. 開花期間は 7 月中下旬より 8 月中下旬に及び開花盛期は 7 月下旬より 8 月上旬までである。

3. 1 個體平均 120 內外の頭狀花を附け， 1 頭狀花は平均 70 內外の筒狀花 在含む。1 頭花の開花期間は 2 日である。

4. 開花順序は主蒙より下部の枝一と有限的に進み， 1 頭花內の筒狀花は周 圍より中心へ之無限的に開花す。

5. 筒狀花の開花は朝より午後 1 時までに完了し, 自家授精に便なる構造を 有す。

6. 稔實步合汢平均 $70 \%$ 內外であり，自殖他家授粉に依る差異は認め難い。

7. 分肢枝に依る稔實步合の差異は認められない。

8. 大雨は授精を大いに妨げる。

9. 種子は主蒙部のものが一番重く，1 分岐枝上では頂部のものが最も重い。 文

獻

（1）喜田茂一郎: 蔬荣園藝全書: 132-133

（2）富樫常治：蔬荣栽培講載： 229

（3）近藤萬太郎，笠原安夫：探種に關する實驗的研究，II牛蒡の種子の熟度々生育 並びに抽苔との關係．農學研究，22：121-155

（4）木島常司: 胡維葡の授粉顛末. 園藝の研究 26, (昭和 6 年 3 月)

（5）江口庸雄：葱頭の探種量と開花期及天候との關俰に就て。千葉高等園藝學校學 術報告第 3 號 (昭和 10 年 4 月)

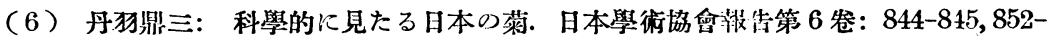
853 (昭和 5 年)

(7) Jones and Rosa: Truck crop plant: 487-488

(8) KNUTн: Handbook of flower pollination: 656-657 